\title{
Comparative Assessment of the Antibacterial activity of Three Tephrosia Species against Helicobacter pylori
}

\author{
S. SANDHYA*
}

Department of Pharmacognosy, St. James College of Pharmaceutical Sciences, River Bank, Chalakudy, Trissur-680 307 , India

Sandhya: Antibacterial activity against Helicobacter pylori by three Tephrosia species

\begin{abstract}
The present study was carried out to provide evidence to the traditional use of three species Tephrosia calophylla, Tephrosia maxima and Tephrosia purpurea to treat ulcers in the regions of Andhra Pradesh. The plants were extracted with chloroform, methanol and then subjected to preliminary phytochemical screening. The antibacterial activity of the extracts against Helicobacter pylori was tested in vitro and in vivo. In vitro activity was screened using the disc diffusion method in Brucella agar supplemented with $7 \%$ sheep blood. In vivo activity against Helicobacter pylori was screened in naproxen and Helicobacter pylori-induced ulcers in Swiss mice with triple regimen of clarithromycin, amoxicillin, omeprazole serving as the standard. The parameters evaluated were $\log \mathrm{CFU} / \mathrm{g}$ of stomach tissue, infection status by polymerase chain reaction, rapid test for urease and histopathological studies. Phytochemical screening indicated the presence of similar phytochemicals in all the three extracts. Methanol extracts of the plants exhibited high antibacterial activity in vitro. Tephrosia maxima showed potent activity against Helicobacter pylori-infected ulcer in rodents relative to Tephrosia calophylla and Tephrosia purpurea. Log CFU/g of stomach tissue was observed to be very low after treatment with Tephrosia maxima. Observations on infection status confirmed these findings. These results suggested that Tephrosia maxima to be an effective inhibitor of Helicobacter pylori-infected ulcer. Histopathological studies further supported these results. Mild inflammation and congestion were seen in the gastric mucosa of the mice treated with Tephrosia maxima methanol extract without any ulcer whereas with the other two plant extracts, slight increase in inflammation and congestion was observed.
\end{abstract}

Key words: Helicobacter pylori, histopathological studies, rapid urease test, polymerase chain reaction

Helicobacter pylori is a Gram-negative bacteria, which is microaerophilic with a helical rod like structure that colonizes in human gastric mucous layer predominately cause peptic ulcers in immunecompromised patients ${ }^{[1,2]}$. It is found in stomach along with acid secretion and can damage the tissue of the stomach and duodenum, causing inflammation and ulcers. H. pylori is believed to be transmitted from person to person through the oral cavity.

The International Agency for Research on Cancer and World Health Organization primarily classified H.pylori under group I carcinogen ${ }^{[2,3]}$. More than $50 \%$ of world population has H. pylori in their GIT but most infections are asymptomatic and about $10-15 \%$ of the infected individuals develop chronic inflammation leading to various conditions like atrophic gastritis, peptic ulcer as well as gastric adenocarcinoma. H. pylori infection is very common in India, where a huge population is at a risk of developing ulcers and carcinoma. The conventional triple-therapy treatment of $H$. pyloriinfected ulcers has the drawbacks such as incomplete cure, undesirable side effects, non-compliance among the patients, antimicrobial resistance and high cost of the antibiotics. Hence a need to develop new non-antibiotic antibacterial agents against $H$. pylori infection that are highly effective, safe, and affordable has become an important criteria ${ }^{[3,4]}$. This requirement gave impetus to further screen herbal medicines that are effective against $H$. pylori. As a part of this drive, three plants were selected for a comparative assessment to find the best. Tephrosia calophylla BEDD is a plant with light pink flowers and tuberous root ${ }^{[5]}$. Various bioactive components isolated from the whole plant of

This is an open access article distributed under the terms of the Creative Commons Attribution-NonCommercial-ShareAlike 3.0 License, which allows others to remix, tweak, and build upon the work non-commercially, as long as the author is credited and the new creations are licensed under the identical terms

Accepted 20 March 2018

Revised 05 August 2017

Received 31 January 2017

Indian J Pharm Sci 2018;80(3):460-469 
T. calophylla include 7-Omethylglabranin, kaempferol3-O-b-D-glucopyranoside and tephcalostan $\mathrm{B}, \mathrm{C}, \mathrm{D}^{[6-8]}$. The plant is reported to possess potent hepatoprotective, cytotoxic effect and antiprotozoal activity ${ }^{[9]}$. Tephrosia maxima also known as Galega maxima $\mathrm{L}$ is a herb with pink-coloured flowers and is spread in wasteland and dry forests ${ }^{[5]}$. Flavonoids isolated from the plant included maxima isoflavone $\mathrm{B}, \mathrm{H}$ and 7,8-methylenedioxyisoflavone ${ }^{[10,11]}$. The root of the plant exhibited human red blood cell membrane stabilising and in vitro antacid activity ${ }^{[12,13]}$. T. purpurea Pers. is a shrub ${ }^{[5]}$ that has pinkish blue or purple-coloured flowers. The bioactive principles of the plant reported so far are rotenoids, flavanones, isoflavanones and coumarins ${ }^{[14-16]}$. Various parts of the plant are reported to possess potential anticancer, antimicrobial ${ }^{[17]}$, hepatoprotective $\mathrm{e}^{[18]}$, antiulcer ${ }^{[19]}$, antihyperglcemic ${ }^{[20]}$, antioxidant ${ }^{[21,22]}$, insecticidal and repellent properties ${ }^{[23]}$. In 2009, Chinniah et al. reported in vitro antiH. pylori activity of the methanol fraction of the plant ${ }^{[24]}$.

The three Tephrosia species selected are habitually used by the people of Andhra Pradesh for the management of gastric ulcers. Literature search on the selected plants revealed in vitro anti $H$. pylori activity screening of T. purpurea. In the present study, in vitro and in vivo evaluation of the comparative antiH. pylori effects of these three selected plants is attempted.

\section{MATERIALS AND METHODS}

\section{Plant collection and authentication:}

The plant materials were collected from Talakona regions of Andhra Pradesh. Identification and authentication was done at Sri Venkateswara University, Tirupati, Andhra Pradesh. The prepared herbarium specimens were deposited in the Department of Pharmacognosy, Nalanda College of Pharmacy, Nalgonda, Telangana. The vouchernumbers of the plants were: T. calophylla-NCOP-NLG/ph' $\operatorname{cog} / 2009-10 /$ 010, T. maxima-NCOP-NLG/ph'cog/2009-10/020, T. purpurea- NCOP-NLG/ph'cog/2009-10/011.

\section{Procurement and housing of animals:}

Albino Swiss mice weighing 18-22 g were procured from the National Institute of Nutrition, Hyderabad, Telangana. The animals were caged in standard polypropylene cages in groups of four. The temperature was maintained at $24 \pm 1^{\circ}$, with relative humidity of 45-55 \% and 12:12 $\mathrm{h}$ dark/light cycle. The animals were acclimatized for $2 \mathrm{w}$ under pathogen free conditions. The animals had free access to standard feed and filtered water throughout the experimental protocol. All experimental protocols were approved by the Institutional Animal Ethics Committee (NCOP/ IAEC/approval/41/2012) as per the Committee for the Purpose of Control and Supervision of Experiments on Animals guidelines.

About $500 \mathrm{~g}$ of the dried root powder of three plants were taken and extracted separately with chloroform and methanol in a Soxhlet apparatus for $72 \mathrm{~h}$ at $50^{\circ}$. The resultant crude extract was then made solvent free by using a rotary vacuum evaporator. The colour, consistency and percent yield of the extracts observed and calculated. Preliminary phytochemical screening was performed to identify the chemical constituents $^{[25-27]}$.

\section{Estimation of total phenolic content:}

Folin-Ciocalteu (FC) assay was performed to estimate the total phenolic content of the extracts. An aliquot (1 ml) of gallic acid standard $(20,40,60,80$ and $100 \mathrm{mg} / \mathrm{l}$ ) of extract was added to $9 \mathrm{ml}$ of deionised water in $25 \mathrm{ml}$ volumetric flask. A blank was prepared using deionised water. About $1 \mathrm{ml}$ of FC phenol reagent was incorporated to the mixtures and vigorously shaken. Add $10 \mathrm{ml}$ of $7 \%$ sodium carbonate solution to the mixtures after $5 \mathrm{~min}$. The solutions were diluted to $25 \mathrm{ml}$ with deionised water and mixed. After incubating at room temperature for $90 \mathrm{~min}$, the absorbance was measured at wavelength of $750 \mathrm{~nm}$ using UV/Vis spectrophotometer. The obtained phenolic content was expressed as mg gallic acid equivalents/g crude drug. The analysis of the samples was done in duplicates ${ }^{[28,29]}$.

\section{Estimation of total flavonoid content:}

Aluminium chloride colorimetric assay was performed to estimate the total flavonoid content. About $1 \mathrm{ml}$ of extracts or quercetin standard solution $(20,40,60,80$ and $100 \mathrm{mg} / \mathrm{l}$ ) was added to $4 \mathrm{ml}$ of deionised water in a volumetric flask. About $0.3 \mathrm{ml} 5 \% \mathrm{NaNO}_{2}$ was added and left for $5 \mathrm{~min}$. Then $0.3 \mathrm{ml} 10 \%$ aluminium chloride was added and at $6^{\text {th }}$ min, $2 \mathrm{ml}$ of $1 \mathrm{M}$ sodium hydroxide was added. Then the total volume was made up to $10 \mathrm{ml}$ with deionised water and the solution was mixed well and the absorbance was measured against prepared reagent blank at $510 \mathrm{~nm}$. Total flavonoid content was expressed as milligram quercetin equivalents/100 $\mathrm{g}$ crude drug and all the samples were analysed in duplicates ${ }^{[28,30]}$. 


\section{Safety evaluation:}

Safety evaluation studies were conducted on female Swiss albino mice weighing 18-22 $\mathrm{g}$. The age of animals at the commencement of dosing was between 8 and $12 \mathrm{w}$ old. The mice were divided into four groups with three animals in each group. Group I-IV were administered 5, 50, 300 and $2000 \mathrm{mg} / \mathrm{kg}$ per oral (p.o.) in single dose by oral gavaging. For about one week, all mice were under observation. Toxicity testing was performed according to the AOT 425 guidelines laid down by Organisation for Economic Co-operation and Development ${ }^{[31]}$.

\section{Assessment of antibacterial activity:}

Freeze dried bacterial strains of Pseudomonas aeruginosa (MTCC 741), Bacillus subtilis (MTCC 441), Escherichia coli (MTCC 443) and Staphylococcus aureus (MTCC 96) were procured from microbial type culture collection, Chandigarh. The antibacterial activity was performed on two Gram-positive bacteria B. subtilis and $S$. aureus and two Gram-negative bacteria $P$. aeruginosa and E. coli employing the KirbyBauer method using disc-agar diffusion method ${ }^{[32]}$. Chloroform and methanol extracts of the three plants at a concentration of $10,25,50$ and $100 \mathrm{mg} / \mathrm{ml}$ were prepared and $30 \mu 1$ of the test solution was incorporated into sterile disc. It was then placed on the inoculated nutrient agar plates and incubated at $37^{\circ}$ for $24 \mathrm{~h}$. Gentamycin $(1 \mathrm{mg} / \mathrm{ml})$ and water were employed as standard and control, respectively. The experiment was performed in triplicates and the results were expressed as mean of inhibition diameters (mm).

\section{Evaluation of in vitro anti $H$. pylori activity:}

The strain of $H$. pylori used in this study was GC10 isolated from gastric carcinoma subject. The strain was seeded on Brucella broth media and grown for $48 \mathrm{~h}$ under microaerophilic conditions at $37^{\circ}$. Bacterial growth was taken from the plates and re-suspended in sterile saline. The inoculum was prepared to contain $\sim 10^{8} \mathrm{CFU} / \mathrm{ml}$ by adjusting the suspension to match the McFarland number 4 turbidity standard ${ }^{[33]}$. The Kirby and Bauer disc diffusion susceptibility test was used for primary screening of susceptibility of $H$. pylori to the bioactive compound. The tests were performed according to recommendations of the National Committee for Clinical Laboratory Standards (1993), modified to the needs of $H$. pylori. The inoculum prepared as above was inoculated onto Brucella agar supplemented with $7 \%$ sheep blood. Different concentration of the chloroform and methanol root extract from 0.05 to $5 \mathrm{mg}$ /disc of the three plants were placed on to the inoculated plates with the sterile dispenser and incubated in micro aerobic atmosphere at $37^{\circ}$ for 3-5 d. Water and amoxicillin were used as the control and standard, respectively ${ }^{[34]}$. All the procedures were performed in triplicates.

\section{Effect of bioactive compound on $H$. pylori morphology:}

To check the effect of bioactive compound on the morphology of $H$. pylori; slides were prepared from the above samples, stained with modified Gram stain and observed under oil immersion.

\section{Naproxen-induced and $\boldsymbol{H}$. pylori-infected ulcers:}

The mice were grouped into 5 with 6 animals in each group. Methanol extracts of the three plants were suspended in $0.5 \% \mathrm{w} / \mathrm{w}$ sodium $\mathrm{CMC}$ and was administered at the rate of $120 \mathrm{mg} / \mathrm{kg} / \mathrm{d}$ orally. A triple drug regimen (clarithromycin $25 \mathrm{mg} / \mathrm{kg}$, amoxicillin 50 $\mathrm{mg} / \mathrm{kg}$, omeprazole $20 \mathrm{mg} / \mathrm{kg}$; $\mathrm{CAO}$ ) suspended in $0.5 \%$ w/w sodium $\mathrm{CMC}$ was administered. The control mice were administered $1 \mathrm{ml}$ of $0.5 \% \mathrm{w} / \mathrm{w}$ sodium CMC. Ulcers were induced by the modified method described by Kim et al. $2005^{[35]}$. All animals were starved for $24 \mathrm{~h}$ before the experiment. Naproxen was administered $(30 \mathrm{mg} / \mathrm{kg}$, p.o.) for $3 \mathrm{~d}$ to produce ulcers. After induction of ulcers, the animals were subjected to infection by administering $1 \mathrm{ml}$ of $H$. pylori as suspension in Brucella broth media for seven consecutive days to the ulcerated animals. The number of bacteria/ml was adjusted to $10^{8} \mathrm{CFU} / \mathrm{ml}$ using McFarland's turbidity standards as followed by Ibrahim et al. ${ }^{[36]}$. After this dosing, test or standard drugs were given, for the next seven days. To avoid coprophagy the mice were housed in meshed cages. At the end of 4,7 and $10^{\text {th }} \mathrm{w}$, the mice were sacrificed by cervical dislocation, identified and established the infection status by opening the abdomen by midline incision. The stomach was isolated and opened along the greater curvature to expose inner surface. The inner surface was washed thoroughly with normal saline and scanned for analysis. Quantitative determination of the bacteria was done by amplifying the DNA extracted from the homogenized gastric mucosa of the mice according to standard protocol. The bacterial DNA was amplified by polymerase chain reaction (PCR) machine. The amplified DNA was run on the gel documentation machine to determine the exact amount of the bacterial DNA present in each sample. Gastric mucosal damage was assessed by 
staining with eosin-haematoxylin $\operatorname{stain}^{[36-38]}$. After the last dose administration the animals were fasted for a day and then sacrificed to obtain the sample by incising the mucosa of the pylorus and antrum region of the stomach. About $200 \mathrm{mg}$ of sample from the pyloric antrum portion of mice was minced and homogenised under aseptic conditions in a pre-sterilised mortar and pestle.

\section{Inoculation of the homogenate on the culture plates:}

About $200 \mathrm{mg}$ of sample with $2 \mathrm{ml}$ of sterile foetal bovine serum broth were taken and $1 \mathrm{ml}$ of homogenate was added to $9 \mathrm{ml}$ of Brucella broth and subsequently serially diluted using sterile Brucella broth till dilution of 1:108 was achieved. Then, $100 \mu 1$ of these dilutions were inoculated into Brucella agar plates included with antibiotics. These plates were incubated under microaerophilic conditions at $37^{\circ}$ for five days. The growth of $H$. pylori colonies were recognized by formation of small grey translucent water droplet like colonies and established by positive rapid urease test (RUT). Numbers of CFU were expressed as $\log \mathrm{CFU} / \mathrm{g}$ of gastric tissue ${ }^{[36-38]}$.

\section{Determination of $\boldsymbol{H}$. pylori infection status:}

The parameters carried out to determine the infection status were RUT, determination of $\log \mathrm{CFU} / \mathrm{g}$ of gastric tissue, extraction of DNA to be amplification of $16 \mathrm{~S}$ rRNA gene by PCR and histopathological changes ${ }^{[36]}$.

\section{RUT:}

The RUT solution was prepared and the isolated pyloric tissue was immediately immersed in it, which was taken in the sterilized Eppendorf tube. The change of colour from yellow to red within 10 min indicated the presence of H. pylori ${ }^{[38]}$.

\section{DNA isolation:}

DNA isolation from gastric tissue was performed as mentioned by Tiwari et al. ${ }^{[37]}$. Briefly, the tissue samples were suspended in $250 \mu \mathrm{l}$ of digestion buffer II ( $\mathrm{NaCl}$, Tris-HCl, EDTA and SDS) containing $100 \mu \mathrm{g} / \mathrm{ml}$ of proteinase $\mathrm{k}$. To this, $250 \mu \mathrm{l}$ of digestion buffer I ( $\mathrm{NaCl}$, Tris-HCl, EDTA) was added and incubated at $56^{\circ}$ overnight. DNA was extracted with an equal volume of phenol and chloroform and then precipitated with isopropanol. The DNA pellets were washed thrice with 80,75 and $70 \%$ ethanol, respectively, and finally re-suspended in 50-100 $\mu$ of sterile water for injection. All the steps were performed in aseptic conditions to minimize contamination.

\section{PCR amplification of 16S rRNA gene:}

PCR amplification was performed according to the procedure described by Tiwari et al. ${ }^{[37]}$. The template DNA isolated from gastric tissue was added to the reaction mixture containing magnesium chloride, dNTPs, primer and Taq polymerase. PCR amplification was performed in a thermal cycler. DNA of the ATCC 26695 type strain was used as a positive control in each batch of PCR assays while negative control consisted of all the reagents of the master mix excluding the template DNA. The primers were 16S rRNA F and 16S rRNA R. The PCR-amplified samples were analysed by agarose gel electrophoresis. Each amplified sample was added to the loading buffer (glycerol $50 \%$, bromophenol blue and $\mathrm{NaOH}$ ) and subjected to electrophoresis in a $2 \%$ agarose gel. The image was captured after examining the gel in the gel documentation instrument ${ }^{[37]}$.

\section{Histopathological examination}

Fine microtome sections of pylorus portion of the stomach were fixed in formalin and were stained with eosin-haematoxylin stain to determine the presence of H. pylori-induced congestion and inflammation. The images were captured at $40 \mathrm{X}$ magnification.

\section{Infection status:}

The infection was determined at the end of 4, 7 and $10^{\text {th }} \mathrm{w}$ in the animals. The infection of $H$. pylori was ameliorated up to varying extents in the different treatment groups of animals.

\section{RESULTS AND DISCUSSION}

Percent yield, consistency and nature of phytoconstituents in the extracts of three plants are tabulated in Table 1. The total phenolic content and flavonoid content in the methanol extract were determined to be more than that present in the chloroform extract (Table 2).

Before commencing the antiH. pylori activity, initial screening of the antibacterial activity of the three plant extracts were evaluated on routine bacterial strains. This investigation revealed that $T$. calophylla and $T$. purpurea possessed potent bactericidal activity against $B$. subtilis, whereas $T$. maxima proved to be less effective against these bacteria (Table 3). T. purpurea was found to be a potent inhibitor of $S$. aureus when compared to the other two plants as well as the standard gentamycin (Table 3). The methanol and chloroform extract of T. maxima (TMM and TMC) and methanol 
TABLE 1: NATURE OF THE EXTRACTS AND THE PHYTOCONSTITUENTS PRESENT

\begin{tabular}{|c|c|c|}
\hline $\begin{array}{l}\text { Name of the } \\
\text { extract }\end{array}$ & $\%$ Yield (w/w) & Consistency \\
\hline TCC & $28 \% w / w$ & Brick red flaky shiny po \\
\hline TCM & $16 \% w / w$ & Reddish-brown sticky $r$ \\
\hline TMC & $28 \% w / w$ & Brick red powder \\
\hline TMM & $16 \% w / w$ & Reddish-brown sticky \\
\hline $\mathrm{TPC}$ & $25 \% w / w$ & Reddish-brown powc \\
\hline TPM & $26 \% w / w$ & Reddish-orange sticky \\
\hline \multirow{2}{*}{\multicolumn{3}{|c|}{$\begin{array}{l}\text { Similar chemical constituents were seen in all the methanol extrac } \\
\text { chloroform extracts } \\
\text { TABLE 2: TOTAL PHENOLIC AND FLAVONOIDS } \\
\text { CONTENT }\end{array}$}} \\
\hline & & \\
\hline Extract & $\begin{array}{l}\text { Total phenolic } \\
\text { content (GAE/g) }\end{array}$ & $\begin{array}{c}\text { Total flavonoid } \\
\text { content }(\mathrm{QE} / 100 \mathrm{~g})\end{array}$ \\
\hline TCM & $23.112 \pm 0.0112$ & $12.267 \pm 0.0229$ \\
\hline TCC & $19.1310 \pm 0.035$ & $7.023 \pm 0.0128$ \\
\hline TMM & $25.198 \pm 0.0265$ & $15.981 \pm 0.0298$ \\
\hline TMC & $15.9870 \pm 0.0235$ & $6.633 \pm 0.0128$ \\
\hline TPM & $22.198 \pm 0.198$ & $10.125 \pm 0.0261$ \\
\hline TPC & $14.070 \pm 0.0235$ & $2.246 \pm 0.0128$ \\
\hline
\end{tabular}

Total phenolic and flavonoid content were found to be highest in methanol extract of three plants than the chloroform extracts

extract of T. calophylla (TCM) were found to be better inhibitors of E. coli than T. purpurea (Table 3).

The extracts TCM, TMM and methanol extract of T. purpurea (TPM) at concentrations ranging from 0.1 to $5 \mathrm{mg} /$ disc showed good inhibitory activity against H. pylori with TMM exhibiting in vitro inhibition at as low as $0.01 \mathrm{mg} /$ disc concentration. On the contrary, TMC and chloroform extracts of T. purpurea (TPC) were found to be less active against $H$. pylori with inhibition zone as low as $2.33 \pm 0.33$ and $5.667 \pm$ $0.88 \mathrm{~mm}$ (Table 4). The chloroform extract of T. calophylla (TCC) did not inhibit even at $5 \mathrm{mg} / \mathrm{disc}$ concentration. Methanol extracts of the plant were found be highly active against $H$. pylori whereas the chloroform extracts showed very weak or no activity on the H. pylori strain. The morphology of $H$. pylori stained with modified Gram's stain, revealed presence of spiral or curved-shaped organisms of $H$. pylori, which indicated that the extract did not alter the morphology of the strain.

Quantitative determination of the bacteria in the gastric mucosa was reflected in this test. In the CAO-treated animals, the bacterial load was below the detection limit at the end of 4,7 and $10^{\text {th }} \mathrm{W}$ of study. In the TCM-

treated animals, the bacterial load was found to be $7.6 \pm 0.18,7.5 \pm 0.03$ and $6.7 \pm 0.22 \log \mathrm{CFU} / \mathrm{g}$ of gastric tissue. In the TMM-treated animals the bacterial load was found to be $3.2 \pm 0.96,3.6 \pm 0.03$ and $3.1 \pm 0.06 \mathrm{log}$ $\mathrm{CFU} / \mathrm{g}$ of gastric tissue (fig. 1). In the TPM-treated animals the bacterial load was found to be $7.2 \pm 0.55$, $6.2 \pm 0.62$ and $5.5 \pm 0.20 \mathrm{log} \mathrm{CFU} / \mathrm{g}$ of gastric tissue. From these observations TMM appeared to exert a greater inhibitory effect on $H$. pylori compared to TCM and TPM.

H. pylori exhibited strong urease activity. The urease enzyme produced thus metabolizes urea into ammonia and carbon dioxide, via the formation of bicarbonate. This causes a detectable change in the $\mathrm{pH}$ of the medium, which can be observed, by a change in the colour of the medium from golden yellow to pink within seconds of inoculation of $H$. pylori colonies. PCR and RUT results identically established that TMM was able to inhibit the infection of the gastric mucosa, as at the end of $10^{\text {th }} \mathrm{W}$ only $2 / 6$ animals were found to be infected (fig. 2). In CAO-treated animals, the infection was ameliorated in the $4^{\text {th }} \mathrm{W}$ itself (Table 5). In TPM and TCM-treated animals, the infection was ameliorated to a lesser extent as $4 / 6$ animals were found to be infected at the end of $10 \mathrm{w}$ (Table 6).

The histopathological evaluation suggests that CAOtreated animals were devoid of gastric damage. However the vehicle-treated animals demonstrated significant congestion and inflammation due to H. pylori infection. In the TMM-treated animals, the congestion and inflammation was found to be less in comparison to the vehicle-treated animals (Table 7). TPM and TCM-treated animals demonstrated moderate damage to the gastric mucosa. The histopathological investigation performed on the stomach of the 
TABLE 3: ANTIBACTERIAL ACTIVITY OF T. CALOPHYLLA, T. MAXIMA AND T. PURPUREA BY DISC DIFFUSION METHOD

\begin{tabular}{|c|c|c|c|c|c|c|c|c|}
\hline \multirow{3}{*}{$\begin{array}{l}\text { Micro } \\
\text { organisms }\end{array}$} & \multicolumn{3}{|c|}{$\mathrm{TCM}$} & \multicolumn{3}{|c|}{ TCC } & \multirow{2}{*}{$\begin{array}{c}\text { Standard } \\
\text { Gentamycin } \\
10 \mu \mathrm{g} / \mathrm{ml}\end{array}$} & \multirow{2}{*}{$\begin{array}{c}\text { Control } \\
\text { Water }\end{array}$} \\
\hline & $\begin{array}{c}0.1 \\
\mathrm{mg} / \mathrm{ml}\end{array}$ & $0.3 \mathrm{mg} / \mathrm{ml}$ & $0.5 \mathrm{mg} / \mathrm{ml}$ & $0.1 \mathrm{mg} / \mathrm{ml}$ & $0.3 \mathrm{mg} / \mathrm{ml}$ & $0.5 \mathrm{mg} / \mathrm{ml}$ & & \\
\hline & \multicolumn{8}{|c|}{ Zone of inhibition $(\mathrm{mm})$} \\
\hline B. subtilis & $8.34 \pm 1.16$ & $11.29 \pm 2.9$ & $14.76 \pm 1.6$ & $9.66 \pm 1.76$ & $10.11 \pm 1.36$ & $10.76 \pm 1.16$ & $15.67 \pm 1.16$ & 0 \\
\hline S. aureus & $13.66 \pm 1.16$ & $14.76 \pm 1.3$ & $16 \pm 2.13$ & $11.62 \pm 1.13$ & $11.88 \pm 2.13$ & $13 \pm 1.16$ & $14.67 \pm 0.58$ & 0 \\
\hline \multirow[t]{2}{*}{ E. coli } & $8.62 \pm 0.93$ & $12.98 \pm 1.13$ & $16.43 \pm 2.1$ & $7.34 \pm 1.16$ & $7.88 \pm 2.13$ & $8.98 \pm 1.19$ & $15.0 \pm 0.0$ & 0 \\
\hline & & TMM & & & TMC & & Standard & Control \\
\hline \multirow[t]{2}{*}{$\begin{array}{l}\text { Micro } \\
\text { organisms }\end{array}$} & $\begin{array}{c}0.1 \\
\mathrm{mg} / \mathrm{ml}\end{array}$ & $0.3 \mathrm{mg} / \mathrm{ml}$ & $0.5 \mathrm{mg} / \mathrm{ml}$ & $0.1 \mathrm{mg} / \mathrm{ml}$ & $0.3 \mathrm{mg} / \mathrm{ml}$ & $0.5 \mathrm{mg} / \mathrm{ml}$ & $\begin{array}{c}\text { Gentamycin } \\
10 \mu \mathrm{g} / \mathrm{ml}\end{array}$ & Water \\
\hline & \multicolumn{8}{|c|}{ Zone of Inhibition (mm) } \\
\hline B. subtilis & $10.14 \pm 1.15$ & $11.79 \pm 2.9$ & $12.96 \pm 1.91$ & $9.86 \pm 1.86$ & $10.11 \pm 1.23$ & $11.76 \pm 1.24$ & $15.67 \pm 1.16$ & 0 \\
\hline S. aureus & $9.26 \pm 1.16$ & $11.76 \pm 1.3$ & $13.89 \pm 2.13$ & $9.62 \pm 1.13$ & $11.88 \pm 2.13$ & $12.77 \pm 1.16$ & $14.67 \pm 0.58$ & 0 \\
\hline \multirow[t]{2}{*}{ E. coli } & $9.62 \pm 1.93$ & $12.98 \pm 1.13$ & $17.43 \pm 2.1$ & $7.34 \pm 1.16$ & $10.88 \pm 1.13$ & $12.98 \pm 1.89$ & $15.0 \pm 0.0$ & 0 \\
\hline & & TPM & & & TPC & & Standard & Control \\
\hline \multirow[t]{2}{*}{$\begin{array}{l}\text { Micro } \\
\text { organisms }\end{array}$} & $\begin{array}{c}0.1 \\
\mathrm{mg} / \mathrm{ml}\end{array}$ & $0.3 \mathrm{mg} / \mathrm{ml}$ & $0.5 \mathrm{mg} / \mathrm{ml}$ & $0.1 \mathrm{mg} / \mathrm{ml}$ & $0.3 \mathrm{mg} / \mathrm{ml}$ & $0.5 \mathrm{mg} / \mathrm{ml}$ & $\begin{array}{c}\text { Gentamycin } \\
10 \mu \mathrm{g} / \mathrm{ml}\end{array}$ & Water \\
\hline & \multicolumn{8}{|c|}{ Zone of inhibition ( $\mathrm{mm})$} \\
\hline B. subtilis & $10.44 \pm 1.66$ & $11.29 \pm 2.9$ & $12.76 \pm 1.6$ & $8.76 \pm 1.76$ & $10.11 \pm 1.36$ & $12.86 \pm 1.11$ & $15.67 \pm 1.16$ & 0 \\
\hline S. aureus & $23.66 \pm 1.16$ & $24.76 \pm 1.3$ & $26.23 \pm 2.13$ & $7.62 \pm 1.33$ & $12.78 \pm 2.13$ & $19.12 \pm 1.16$ & $14.67 \pm 0.58$ & 0 \\
\hline E. coli & $8.92 \pm 0.93$ & $9.98 \pm 1.83$ & $11.43 \pm 2.28$ & $8.34 \pm 1.16$ & $8.88 \pm 2.78$ & $10.98 \pm 2.19$ & $15.0 \pm 0.0$ & 0 \\
\hline
\end{tabular}

The experimental data obtained were expressed as mean $\pm S D$, where $n=3$

TABLE 4: EVALUATION OF IN VITRO ANTIH. PYLORI ACTIVITY

\begin{tabular}{|c|c|c|c|c|c|}
\hline \multicolumn{6}{|c|}{ Zone of inhibition (mm) } \\
\hline Plant extract & 5 (mg/disc) & 1 (mg/disc) & 0.5 (mg/disc) & 0.1 (mg/disc) & 0.05 (mg/disc) \\
\hline TCM & $20.67 \pm 0.667$ & $12 \pm 1.528$ & $5 \pm 1.0$ & -- & -- \\
\hline TCC & --- & --- & -- & --- & --- \\
\hline TMM & $65 \pm 2.0$ & $44.33 \pm 1.453$ & $23 \pm 1.55$ & $7 \pm 0$ & $--\cdot$ \\
\hline TMC & $5.667 \pm 0.88$ & --- & -- & --- & --- \\
\hline TPM & $36 \pm 1.732$ & $25.33 \pm 1.753$ & $14 \pm 2.517$ & --- & --- \\
\hline TPC & $2.33 \pm 0.33$ & $--\cdot$ & -- & -- & $--\cdot$ \\
\hline $\begin{array}{l}\text { Amoxicillin } \\
\text { (standard) }\end{array}$ & $65 \pm 3.055$ & $43.33 \pm 1.856$ & $20.33 \pm 0.6667$ & $6.33 \pm 0.6667$ & $3.00 \pm 0.5774$ \\
\hline $\begin{array}{l}\text { Water } \\
\text { (control) }\end{array}$ & --- & --- & --- & --- & --- \\
\hline
\end{tabular}

The experimental data obtained were expressed as mean $\pm S D$, where $n=3$

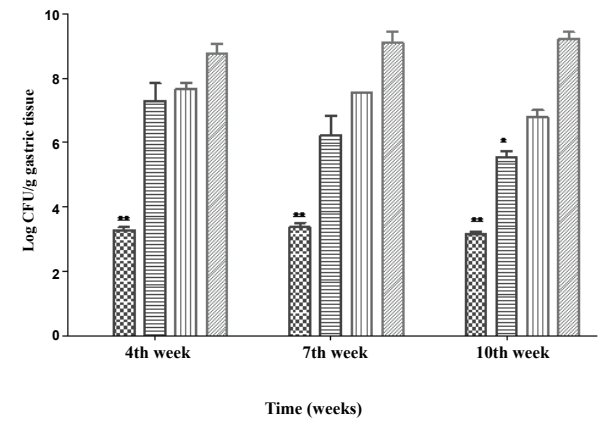

Fig. 1: Log CFU/gram of gastric tissue

The experimental data obtained were expressed as mean \pm SD, where $n=6$; comparison between the groups were analysed by One-way Analysis of Variance (ANOVA) using Dunnett multiple comparisons test by considering test vs. control. The differences were considered to be statistically significant when **p<0.05. CAO; TMM $120 \mathrm{mg} / \mathrm{kg}$; 回 TPM $120 \mathrm{mg} / \mathrm{kg}$; 而 TCM $120 \mathrm{mg} / \mathrm{kg}$; matrol control

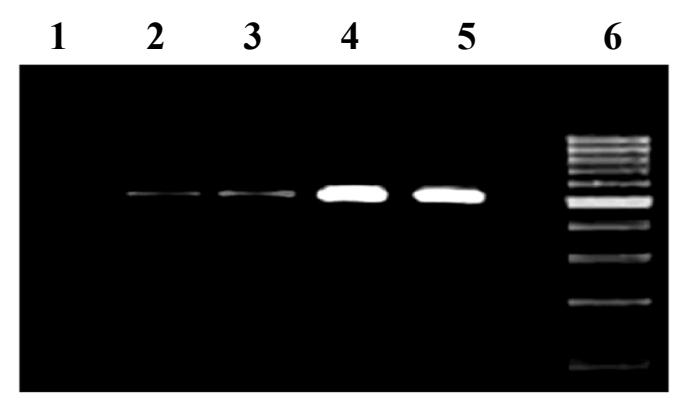

Fig. 2: Polymerase chain reaction

Typical gel image showing $16 \mathrm{~S}$ rRNA amplification of $H$. pylori. Successful amplification of 534 base pair product of 16S rRNA gene from the DNA isolated from the pyloric antrum of the $\boldsymbol{H}$. pylori infected animals. Lane 1: amplicon using SWFI instead of DNA (-ve control); lane 2-4: amplicons using the DNA isolated from the gastric mucosa of infected animals; Lane 5: amplicon using DNA from strain ATCC 26695 (+ve control); lane 6: DNA ladder 100 base pair 
ulcerated mice revealed that the animals treated with standard drug regimen showed no mucosal epithelial cell inflammation, edema or congestion. The gastric mucosa and the blood vessels were found to be normal (fig. 3). The animals treated with TCM extract showed inflammatory cells and edema in the mucosal region along with inflammatory cell infiltration in lamina propia also known as sub mucosal inflammation and mild ulcer (fig. 4A). The gastric mucosal region showed mild congestion, edema and inflammation in the animals treated with TMM (fig. 4B). The mucous cells comprise the lining epithelium that covers the inner surface of the stomach, which is in direct contact with the lumen and the apical portions of these cells are occupied by dense discrete granules. The parietal or oxyntic cells showed mild edema for the animals treated with TMM. Mild inflammatory cell infiltration was also observed. Though the histology of the stomach of the mice treated with TMM showed mild inflammation, edema, congestion, inflammatory

TABLE 5: STATUS OF $\boldsymbol{H}$. PYLORI INFECTION BY POLYMERASE CHAIN REACTION

\begin{tabular}{lccc}
\hline Weeks & 4 & 7 & 10 \\
\hline No. of infected mice in treatment groups & & & \\
Control (vehicle) & $6 / 6$ & $6 / 6$ & $6 / 6$ \\
CAO & $0 / 6$ & $0 / 6$ & $0 / 6$ \\
(Clarithromycin+amoxicillin+omeprazole) & $6 / 6$ & $4 / 6$ & $3 / 6$ \\
TCM $120 \mathrm{mg} / \mathrm{kg} \mathrm{p.o./day}$ & $5 / 6$ & $2 / 6$ & $2 / 6$ \\
TMM $120 \mathrm{mg} / \mathrm{kg} \mathrm{p.o./day}$ & $6 / 6$ & $4 / 6$ & $3 / 6$ \\
\hline
\end{tabular}

This table clearly depicts that TMM is more effective antiH. pylori drug than TCM and TPM

TABLE 6: STATUS OF $\boldsymbol{H}$. PYLORI INFECTION AS DETERMINED BY RAPID UREASE TEST

\begin{tabular}{|c|c|c|c|}
\hline Weeks & 4 & $\overline{7}$ & 10 \\
\hline \multicolumn{4}{|l|}{ No. of infected mice in treatment groups } \\
\hline Control (vehicle) & $6 / 6$ & $6 / 6$ & $6 / 6$ \\
\hline $\begin{array}{l}\text { CAO } \\
\text { (Clarithromycin+amoxicillin+omeprazole) }\end{array}$ & $0 / 6$ & $0 / 6$ & $0 / 6$ \\
\hline TCM 120 mg/kg p.o./day & $6 / 6$ & $4 / 6$ & $3 / 6$ \\
\hline TMM 120 mg/kg p.o./day & $5 / 6$ & $2 / 6$ & $2 / 6$ \\
\hline TPM 120 mg/kg p.o./day & $6 / 6$ & $4 / 6$ & $3 / 6$ \\
\hline
\end{tabular}

TABLE 7: INFLAMMATION AND CONGESTION STATUS OF MICE TREATED WITH THE EXTRACTS OF TCM, TMM AND TPM

\begin{tabular}{lcc}
\hline Drug Treatment & Inflammation & Congestion \\
\hline CAO & - & - \\
TCM & ++ & ++ \\
TMM & + & + \\
TPM & ++ & ++ \\
Vehicle-Treated & +++ & +++ \\
\hline
\end{tabular}

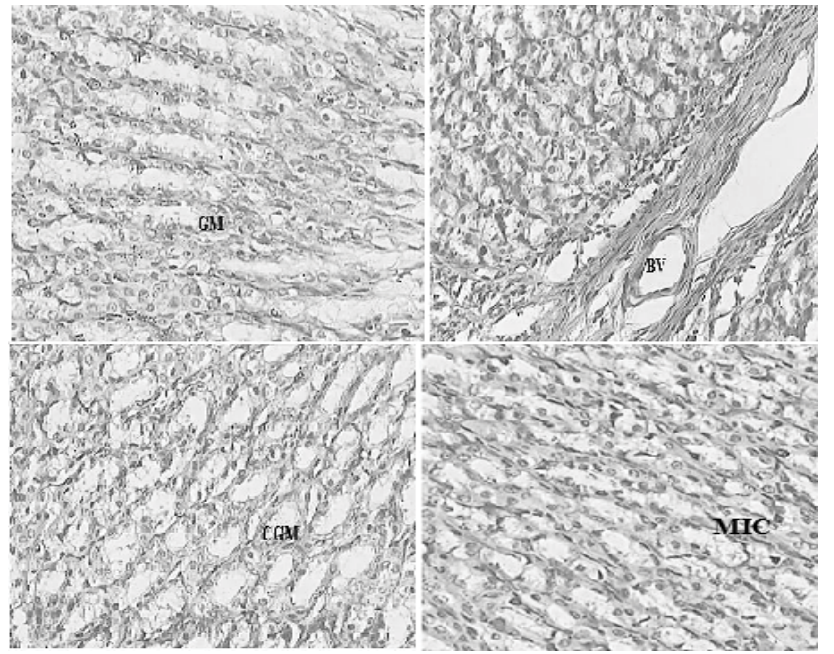

Fig. 3: Histopathological images of animals treated with standard drug

Animals treated with standard drug showing normal gastric mucosa (GM) and blood vessels (BV), mild congestion in gastric mucosa (CGM) and mild inflammation in cells (MIC)

cell infiltration still no ulcerations or ulcer bed was observed, which proved that the plant is a potent inhibitor of $H$. pylori-infected ulcers (fig. 4C). Blood vessel congestion (BVC) was also observed in this group of animals. The animals treated with T. purpurea methanol root extract showed inflammatory cells with infiltration, BVC and no ulceration was observed (fig. 4D). In the control animals, ulcerated mucosa, necrosis and BVC was observed in a severe manner (fig. 5). These results indicated that in vivo antiH. pylori activity of the three extracts was in the following rank order, TMM $>$ TPM $>$ TCM $(120 \mathrm{mg} / \mathrm{kg})$.

Natural products constitute an extremely important source of medicinal plants. Several phytoconstituents were found in the methanol extract of all the three plants. The total phenolic and flavonoid content estimations revealed high amount of these secondary metabolites in extracts of all the three Tephrosia plants. The variation in the concentration of flavonoids in the plants has shown a remarkable change in the pharmacological activity. The antibacterial activity of the three plant extracts was evaluated on B. subtilis, $S$. aureus and $E$. coli before testing their ability to inhibit $H$. pylori in vitro. It was observed that all the three plant extracts possessed good antimicrobial activity. Among these three plants, T. maxima, was the most effective antibacterial against $E$. coli. Hence further evaluation was carried out against $H$. pylori. The virulence factor of $H$. pylori has been attributed to the presence of lipopolysaccharides (LPS) as a component on the cell surface ${ }^{[39]}$ and it is a well-known host 

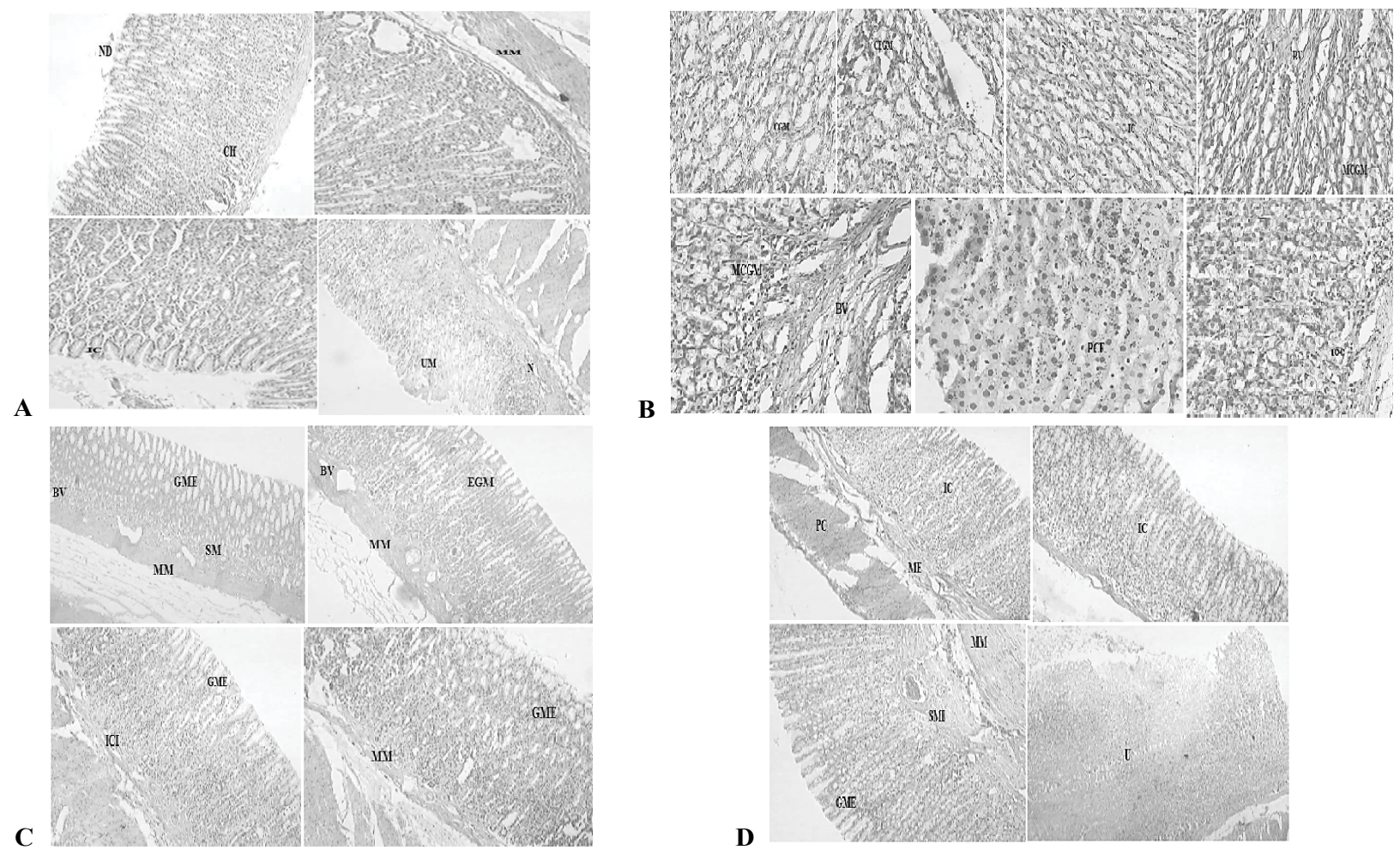

Fig. 4: Histopathological images of animals treated with TCM, TMM and TPM

A. Animals treated with TCM showing necrotic debris (ND), cell infiltration (CIf), inflammatory cells (IC), necrosis (N) and ulcerative mucosa (UM). B. Animals treated with TMM showing mild congestion (CGM), congestion and edema in gastric mucosa (CEGM), mild IC, blood vessels (BV) and mild congestion in gastric mucosa (MCGM), parietal cells with edema (PCE), mild inflammatory cell infiltration in oxyntric cells (IOC- inflammatory oxyntric cells). C. Animals treated with TMM showing no ulcer (BV; GME-gastric mucosal epithelial cells; SM- sub mucosa; MM- muscularis mucosae). But inflammatory cells seen in animals treated with TMM (ICI- inflammatory cell infiltration, GME, MM- muscularis mucosae, PC-parietal cells; ME-muscularis externa; IC-inflammatory cells). D. Animals treated with TPM showing IC, sub mucosal edema (SME), GME and ulcer (U)

immune response stimulator. However it was reported that the LPS of $H$. pylori was with lower virulence as compared to the typical bacterial endotoxins such as E. coli LPS $^{[40-42]}$. The in vitro evaluation against H. pylori activity suggested that the chloroform extract of the three plants exhibited least activity when compared to the methanol extracts. TMM extract was found to be the most active amongst all. It is welldocumented that flavonoids produce antiulcer effect and inhibit growth of $H$. pylori in a dose-dependent manner in vitro ${ }^{[42]}$. The presence of $H$. pylori in the untreated animals was confirmed by PCR and RUT. The amplification of 534 base pair product of $16 \mathrm{~S}$ rRNA gene from the DNA isolated from the pyloric antrum of the $H$. pylori-infected animals was performed and was successful. It was observed that the infection status evaluated by PCR and RUT correlated well with each other. As per the observation, the $\log \mathrm{CFU} / \mathrm{g}$ of gastric tissue from the gastric pyloric antrum was very low in the animals treated with TMM. In the case of CAO-treated animals, the number of CFUs was below the detection limit. In the TMM-treated animals, the bacterial load was significantly less when compared to the vehicle-treated animals $(p<0.01)$ at the end of 4,7 and $10^{\text {th }} \mathrm{W}$ of drug administration. The infection status as evaluated by PCR and RUT showed reduced infection by the end of $10^{\text {th }} \mathrm{W}$ in all the groups, but the group treated with $T$. maxima showed a significant reduction in infection. Histopathological evaluation of the gastric mucosa revealed severe induction of inflammation and $\mathrm{BVC}$ in the control group of animals. The CAO-treated animals were found to have normal blood vessel texture and mild inflammation. In the case of TMM, no ulcer spots or rashes were observed, but mild inflammation and infiltration were seen. Phytochemically it appeared that the high content of phenolic compounds and flavonoids must have been the reason to produce this potent biological activity. T. purpurea showed the second best activity against $H$. pylori. It was observed that the mice showed mild ulcer, inflammatory cells, mild edema in the sub mucosa and gastric mucosa. Mice treated with $T$. calophylla showed mild ulcer 

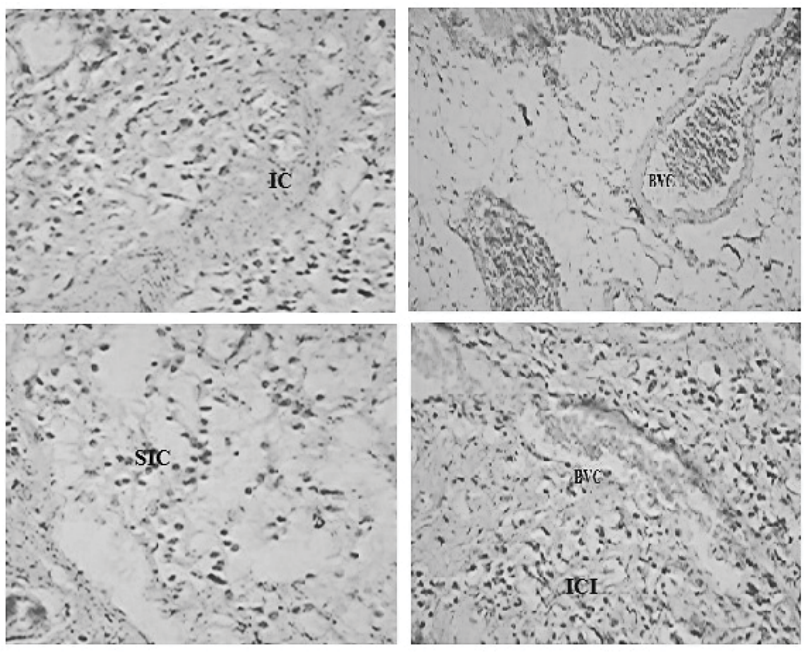

Fig. 5: Histopathological images of control animals

Control animals showing inflammatory cells (IC), sub severe blood vessel congestion (BVC), inflammatory cell infiltration (ICI)

with edema, inflammation and gastric congestion. It was also noted that gastric samples were characterized by necrotic debris, inflammatory cells, necrosis and ulcerative mucosa, mild infiltration of the lamina propria or submucosal inflammation with scattered lymphocytes and neutrophils. No development of glandular atrophy or intestinal metaplasia was observed in the mice treated with the test extracts. Severe necrosis, BVC and inflammation were observed in the vehicle-treated mice. The ability of flavonoids as potent antioxidants and their role in the prevention of ulcers and inflammation are well-documented. Flavonoids generally prevent injury caused by free radicals in various ways $^{[43]}$. They stabilize the ROS by reacting with the reactive compound of the radical. Peptic ulcers in the gastrointestinal tract are usually due to high content of acid and are thus extremely painful. Quercetin is a potent flavonoid entity that plays a very important role in the prevention and treatment of peptic ulcer. Its mechanism is by promoting mucus secretion, thereby serving as gastro protective agent, and it also has been shown to inhibit the growth of H. pylori ${ }^{[44]}$. Thus the present investigation revealed that $T$. maxima could be an antiulcer agent as well as an inhibitor of $H$. pylori both in vitro and in vivo. The ability of this plant extract to exert these effects could be attributed to the presence of phenolic and flavonoids in the extract. Since T. maxima, T. purpurea and T. calophylla were found to exert antiH. Pylori activity, these plants could serve as a better alternative to synthetic drugs. Further studies on isolation and characterisation of exact chemical constituent responsible for the antiulcer and H. pylori inhibitory activity are necessary.

\section{Acknowledgements}

The authors express their great sense of gratitude to the Acharya Nagarjuna University, for allowing access to the library and various other resources. The authors thank Dr. Madhava Chetty, Taxonomist, S.V. University, Tirupati, Andhra Pradesh for identifying and authenticating the plant materials. The authors also thank the Principal and Management of Nalanda College of Pharmacy for help in performing the intended work.

\section{Financial support and sponsorship:}

Nil.

\section{Conflict of interest:}

The authors declare that this paper content has no conflict of interests.

\section{REFERENCES}

1. Gopinath V, Priyadarshini S, MubarakAli D, Mun Fai Loke, Thajuddin N, Naiyf S. Alharbi, et al. Anti-Helicobacter pylori, cytotoxicity and catalytic activity of biosynthesized gold nanoparticles: Multifaceted application. Arabian Journal of Chemistry (Article In press).

2. Sarkar A, De R, Mukhopadhyay AK. Curcumin as a potential therapeutic candidate for Helicobacter pylori associated diseases. World J Gastroenterol 2016;22:2736-48.

3. Shmuely H, Domniz N, Yahav J. Non-pharmacological treatment of Helicobacter pylori. World $\mathrm{J}$ Gastrointest Pharmacol Ther 2016;7(2):171-78.

4. García-Alonso G, Monroy-Noyola A, Contreras-Arellano A, Mariscal-Durand JF, Gálvez-Molina Y, Vázquez-Velázquez A, et al. Preclinical evaluation of anti-Helicobacter sp. activity of Hippocrateace lastroides Kunth and its acute and sub-acute toxicity. BMC Complement Altern Med 2016;16:445.

5. Chetty KM, Sivaji K, Tulasi Rao K. Flowering Plants of Chittoor Dist, A.P, India. Thirupathi: Student Offset Printers; 2008.

6. Hari Kishore P, MopuruVijayaBhaskar MR, Gunasekar D, Murthy MM, CristelleCaux BB. A New Coumestan from Tephrosia calophylla. Chem Pharm Bull 2003;51:194-96.

7. Reddy RV, Khalivulla S, Reddy BA, Reddy MV, Gunasekar D, Deville A, et al. Flavonoids from Tephrosia calophylla. Nat Prod Commun 2009;4:59-62.

8. Ganapaty S, Srilakshmi GV, Pannakal ST, Rahman H, Laatsch $\mathrm{H}$, Brun R. Cytotoxic benzil and coumestan derivatives from Tephrosia calophylla. Phytochemistry 2009;70(1):95-99.

9. Adinarayana K, Jayaveera KN, Mallikarjuna Rao P, Madhusudhana Chetty C, Sandeep DK, Swetha C, et al. Acute Toxicity and Hepatoprotective effect of Methanolic extract of Tephrosia calophylla. Res J Med Plant 2011;5(3):266-73.

10. Venkata Rao E, Sree Rama Murthy M. Further studies on the isoflavones of Tephrosia maxima. Phytochemistry 1985;24(4):875-76.

11. Venkata Rao E, Sree Rama Murthy M, Ward SR. Nine isoflavones from Tephrosia maxima: The isolation and characterisation of nine closely related 3',4'-disubstituted 
isoflavones from the aerial parts and roots of Tephrosia maxima. Phytochemistry 1984;23(7):1493-501.

12. Sandhya S, Venkat Ramana K, Vinod KR, Chaitanya $\mathrm{RK}$, Chandrasekhar J, Sudhakar $\mathrm{K}$, et al. Membrane stabilizing potency of Two Tephrosia species. J Phytology 2010;2(6):42-6.

13. Sandhya S, Venkata Ramana K, Vinod KR. A Comparative Evaluation of In Vitro Antacid Activity of Two Tephrosia Species Using Modified Artificial Stomach Model. Hygeia J D Med 2015;7(2):9-17.

14. Zafar R, Mujeeb M. Rotenoids and rutin in callus cultures of Tephrosia purpurea (L) pers. Indian J Pharm Sci 2002;64(3):217-21.

15. Chang LC, Gerhauser C, Song L, Farnsworth NR, Pezzute JM, Kinghorn AC. Activity-guided Isolation of Constituents of Tephrosia purpurea with the potential to induce the Phase II Enzyme, Quinone Reductase. J Nat Prod 1997;60(9):869-73.

16. Hegazy ME, Abd el-Razek MH, Nagashima F, Asakawa Y, Paré PW. Rare prenylated flavonoids from Tephrosia purpurea. Phytochemistry 2009;70:1474-77.

17. Deshpande SS, Shah GB. Pharmacological activity of Tephrosia purpurea. AAPS J 2008;10(S2):3453.

18. Jain A, Singhai AK, Dixit VK. A comparative study of ethanol extract of leaves of Tephrosia purpurea Pers and the flavonoid isolated for hepatoprotective activity. Indian J Pharm Sci 2006;68(6):740-43.

19. Deshpande SS, Shah GB, Parmar NS. Antiulcer activity of Tephrosia Purpurea in rats. Indian $\mathrm{J}$ Pharmacol 2003;35(3):168-72.

20. Pavana P, Sethupathy S, Manoharan S. Antihyperglycemic and Antilipidperoxidative effects of Tephrosia purpurea seed extract in streptozotocin induced diabetic rats. Indian J Clin Biochem 2007;22(1):77-83.

21. Soni K, Kumar Suresh P, Saraf MN. Free radical scavenging activity of Tephrosia purpurea linn. Indian J Pharma Sci 2003;65(1):27-30.

22. Soni K, Suresh Kumar P, Saraf MN. Antioxidant activity of fraction of Tephrosia purpurea linn. Indian J Pharm Sci 2006;68(4):456-60.

23. Saxena BN, Dubey DN, Nair AL. Study on the insecticidal and repellent properties of the seed extract of Tephrosia purpurea (Linn.). Def Sci J 1974;24:43-8.

24. Chinniah A, Mohapatra S, Goswami S, Mahapatra A, Kar SK, Mallavadhani UV, et al. Potential of Tephrosia purpurea next term as anti-Helicobacter pylori agent. J Ethnopharmacol 2009;124(3):642-45.

25. Kokate CK. Practical Pharmacognosy. 4th ed. New Delhi: Vallabh Prakashan; 2003.

26. Kokate CK, Purohit AP, Gokhale SB. Text book of Pharmacognosy. 4th ed., New Delhi: Vallabh Prakashan; 2009.

27. Khandelwal KR. Practical Pharmacognosy. 1st ed. Pune: Nirali Prakashan; 2005. p. 27-35.

28. Pourmorad F, Hosseininelir SJ, Shahabimajd N. Antioxidant activity, Phenol and Flavonoid Content of some selected Iranian Medicinal Plants. Afr J Biotechnol 2006;5:1142-45.

29. Prasad NK, Divakar S, Shivamurthy GR, Aradhya SM.
Isolation of a free radical scavenging antioxidant from water spinach (Ipomoea aquatic Forsk). J Sci Food Agric 2005;85:1461-68.

30. Marinova D, Ribarova F, Atanassova M. Total phenolics and total flavonoids in bulgarian fruits and vegetables. J Univ Chem Technol Metallurgy 2005;40:255-60.

31. OECD/OCDE 423, 2001, OECD Guideline for Testing of Chemicals. Retrieved on 15/01/2011.

32. Baur AW, Kirby WM, Sherris JC, Turck M. Antibiotic susceptibility testing by a standard single disk method. Am J Clin Pathol 1966;45:493-96.

33. McNulty C, Owen R, Tompkins D, Hawtin P, McColl K, Price $\mathrm{A}$, et al. Helicobacter pylori susceptibility testing by disc diffusion. J Antimicrob Chemother 2002;49:601-09.

34. Koga T, Kawada H, Utsui Y, Domon H, Ishii C, Yasuda H. In-vitro and in-vivo antibacterial activity of plaunotol, a cytoprotective antiulcer agent against Helicobacter pylori. J Antimicrob Chemother 1996;37:919-29.

35. Kim HJ, Kim SY, Song GG, Park JJ, Chang H. Protective effect of astaxanthin on naproxen induced gastric antral ulceration in rats. Eur J Pharmacol 2005; 514:53-9.

36. Ibrahim M, Khan AA, Tiwari SK, Habeeb M A, Khaja MN, Habibullah CM. Antimicrobial activity of Sapindus mukorossi and Rheum emodi extracts against H. pylori: In vitro and in vivo studies. World J Gastroenterol 2006;12(44):7136-42.

37. Tiwari SK, Khan AA, Ahmed KS, Ahmed I, Kauser F, Hussain MA, et al. Rapid diagnosis of Helicobacter pylori infection in dyspeptic patients using salivary secretion: a non-invasive approach. Singapore Med J 2005;46:224-28.

38. Vaira D, Holton J, Chaira R. Diagnosis of H. pylori: Invasive and Non-invasive tests. Best Pract Res Clin Gastroenterol 2007;21:299-313.

39. Britton S, Papp-Szabo E, Simala-Grant J, Morrison L, Taylor DE, Monteiro MA. A novel Helicobacter pylori cell-surface polysaccharide. Carbohydr Res 2005;340:1605-11.

40. Muotiala A, Helander IM, Pyh $\delta 1 \delta$ L, Kosunen TU, Moran AP. Low biological activity of Helicobacter pylori lipopolysaccharide. Infect Immun 1992;60:1714-16.

41. Matsuyama N, Kirikae T, Kirikae F, Hashimoto M, Amanot $\mathrm{K}$, Hayashi S, et al. Non-standard biological activities of lipopolysaccharide from Helicobacter pylori. J Med Microbiol 2001;50:865-69.

42. Ogawa T, Asai Y, Sakai Y, Oikawa M, Fukase K, Suda Y, et al. Endotoxic and immunobiological activities of a chemically synthesized lipid A of Helicobacter pylori strain 206-1. FEMS Immunol Med Microbiol 2003;36:1-7.

43. Beil W, BirkholzC, Sewing KF. Effects of flavonoids on parietal cell acid secretion gastric mucosal prostaglandin production and Helicobacter pylori growth. Arzneimittelforschung 1995;45:697-700.

44. Middleton E, Kandaswami C, Theoharides TC. The Effects of Plant Flavonoids on Mammalian Cells: Implications for Inflammation, Heart Disease, and Cancer. Pharmacol Rev 2000;52:673-751. 